\title{
Rabies Antibody Titres in Vaccinated Reindeer
}

\author{
By L. Sihvonen, K. Kulonen, T. Soveri and M. Nieminen
}

Department of Production and Vaccines and Department of Virology, National Veterinary Institute; Department of Anatomy and Embryology, College of Veterinary Medicine, Helsinki; and The Finnish Game and Fisheries Research Institute, Reindeer Research, Rovaniemi, Finland.

\begin{abstract}
Sihvonen, L., K. Kulonen, T. Soveri and M. Nieminen: Rabies antibody titres in vaccinated reindeer. Acta vet. scand. 1993, 34, 199-202. - One dose of inactivated, adjuvanted rabies vaccine of cell culture origin (Rabisin) induced good but short-duration immunity in close to $100 \%$ of the 50 semi-domesticated reindeer (Rangifer tarandus tarandus $L$.) vaccinated. Most of the animals (44) had rabies virus antibody titre $\geq 1.5$ $\mathrm{IU} / \mathrm{ml}$ at 38 days after vaccination. Five animals had titre 0.5 IU. Antibody titres were not, however, present 1 year after primary vaccination in most animals. About 1 year (360-413 days) after primary vaccination, 22 of the 39 reindeer that could be sampled had rabies virus antibody titre $<0.5 \mathrm{IU} / \mathrm{ml}$.
\end{abstract}

immunization.

\section{Introduction}

Rabies is a disease of the central nervous system of major importance. Infected wildlife constitute a significant reservoir of rabies virus for humans and domestic animals alike. After sylvatic rabies was detected in southeastern Finland in April 1988 (Finland had been rabies free for 29 years), a field trial on the oral immunization of raccoon dogs and foxes was executed using Tubingen bait. Vaccination of dogs and cats was strongly recommended throughout the country. Vaccination of cattle and horses was also recommended in the area where sylvatic rabies was detected. During the epidemic (Apr. 8, 1988-Feb. 16, 1989) 66 animals were diagnosed as rabid: 48 raccoon dogs, 12 foxes, 2 badgers, 2 cats, 1 dog and 1 young bull (Nyberg et al. 1992). No new rabies cases have been found since this epidemic.

The objective of this study was to determine the rabies virus antibody titres of reindeer after vaccination in the field. The chosen vac- cine is a widely used adjuvanted, inactivated product based on virus produced in cell cultures, the immunogenicity of which has been well documented in many animal species (Blancou 1985), but not to our knowledge in reindeer. In northern Fennoscandia, reindeer - as semi-domesticated mammals - are potentially important vectors of rabies to humans. It is probable that reindeer in the northern Finland would be vaccinated against rabies if a rabies epidemic is detected there in the future. Endemic sylvatic rabies still occurs in Russia, close to the Finnish border, and thus constitutes a permanent risk.

\section{Materials and methods}

Reindeer

The investigation was carried out at the Reindeer Herding Association's experimental station at Kaamanen, Finnish Lapland.

The reindeer (Rangifer tarandus tarandus L.) were freely grazing in natural conditions. 
Table 1. Rabies antibody titres in reindeer after vaccination.

\begin{tabular}{lccc}
\hline \multirow{2}{*}{$\begin{array}{l}\text { Rabies antibody } \\
\text { titre (IU/ml) }\end{array}$} & \multicolumn{3}{c}{ No. animals } \\
\cline { 2 - 4 } & Day 0 & Day 38 & Day 360-413 \\
\hline$<0.5$ & 49 & 0 & 22 \\
0.5 & 1 & 5 & 14 \\
1.5 & 0 & 24 & 3 \\
4.5 & 0 & 10 & 0 \\
13.5 & 0 & 9 & 0 \\
40.5 & 0 & 1 & 0 \\
\hline Sample size & 50 & 49 & 39 \\
\hline
\end{tabular}

\section{Rabies vaccine}

The rabies vaccine used was Rabisin, a commercial inactivated and adjuvanted vaccine prepared in a Nil-cell culture (hamster embryo, monolayer cell culture). The reindeer were vaccinated with Rabisin batch no. 80T992, purchased from Rhone-Merieux, Lyon, France.

\section{Vaccination and collection of sera}

Fifty reindeer were vaccinated against rabies at Kaamanen. One dose of Rabisin vaccine (1 $\mathrm{ml}$ ) was administered intramuscularly in the left scapular muscles of the reindeer. The vaccinated reindeer were 1.5 years or older (range 1.5 - 11.5 years). Each reindeer was blood-sampled immediately before vaccination in September 1988, with a second blood sample taken 38 days later. A third blood sample was taken from the remaining reindeer 360 to 413 days after vaccination.

\section{Antibody determination}

The rabies virus neutralizing antibodies were detected by a modification of the RFFIT-test (Smith et al. 1973). Briefly, the sera were titrated on a 96-well microtitre plate in 3-fold dilutions after predilution 1:10. The sera and the Challenge Virus Strain (rabies virus,
WHO, Tubingen, Germany) were incubated at $37^{\circ} \mathrm{C}$ for $90 \mathrm{~min}$, and then $\mathrm{BHK}$ cells were added. The cultures were fixed after $24 \mathrm{~h}$ and stained with anti-rabies fluorescent conjugate (Behringwerke, Marburg, W-Germany). The challenge dose used was the highest dilution of virus giving $40 \%$ infected cells (fluorescent inclusions). Each time the RFFIT was conducted, a reference serum (WHO, Tubingen, Germany) diluted to contain 0.5 IU of rabies virus neutralizing antibody was used to ensure quality control. Owing to the cytoxicity that sometimes occurs at lower serum dilutions, the results for these sera were reported $<0.5$ $\mathrm{IU} / \mathrm{ml}$.

\section{Results}

The rabies antibody titres are shown in Tables 1 and 2 . At 38 days after primary vaccination, rabies neutralizing antibodytitre $(\geq 0.5 \mathrm{IU} / \mathrm{ml})$ was found in the serum of all 49 reindeer that could be sampled. Most of the animals (44) had rabies antibody titre $\geq 1.5 \mathrm{IU} / \mathrm{ml}$. One of the reindeer that had titre $0.5 \mathrm{IU} / \mathrm{ml}$ at that time also showed the same amount of titre before vaccination and 1 year after vaccination. One year (360-413 days) after vaccination, 17 of the 39 reindeer that could be sampled had titre $\geq 0.5 \mathrm{IU} / \mathrm{ml}$.

\section{Discussion}

The resistance induced by the rabies vaccine is associated with antibody production (Turner 1973, Turner 1978). Neutralizing antibody produced in response to vaccination is an important factor in the protection against rabies infection. Specific antibodies limit the further spread of the rabies virus from the bite wound. Postvaccinal immunity in rabies can be assessed either by challenge experiments in animals or by detecting the presence of neutralizing antibodies in animals.

For human pre-exposure immunization, it is 
Table 2. Individual rabies antibody titres (IU/ml) in reindeer after vaccination.

\begin{tabular}{|c|c|c|c|c|c|c|c|}
\hline \multicolumn{4}{|c|}{ Reindeer } & \multicolumn{4}{|c|}{ Reindeer } \\
\hline No. & Day 0 & Day 38 & Day 360 & No. & Day 0 & Day 38 & Day $375-413$ \\
\hline 171 & 0.17 & 1.5 & 0.5 & 713 & $<0.17$ & NS & 0.5 \\
\hline 521 & $<0.17$ & 13.5 & 0.5 & 227 & $<0.17$ & 0.5 & 0.5 \\
\hline 145 & $<0.17$ & 1.5 & 0.5 & $22 \mathrm{~N}$ & $<0.17$ & 1.5 & 0.17 \\
\hline 723 & 0.17 & 0.5 & 0.5 & M1 & $<0.17$ & 1.5 & 0.5 \\
\hline 163 & $<0.17$ & 13.5 & 1.5 & 85 & $<0.17$ & 1.5 & 1.5 \\
\hline 715 & 0.5 & 0.5 & 0.5 & 251 & $<0.17$ & 1.5 & $<0.17$ \\
\hline 176 & $<0.17$ & 1.5 & 0.17 & 209 & $<0.17$ & 1.5 & 0.17 \\
\hline 895 & $<0.17$ & 1.5 & 0.17 & $7 \mathrm{~N}$ & $<0.17$ & 1.5 & 0.17 \\
\hline 851 & $<0.17$ & 4.5 & 0.17 & $16 \mathrm{~N}$ & $<0.17$ & 1.5 & $<0.17$ \\
\hline 43 & 0.17 & 1.5 & 0.17 & 13 & $<0.17$ & 1.5 & 0.17 \\
\hline 547 & $<0.17$ & 1.5 & 0.17 & 349 & $<0.17$ & 4.5 & 0.17 \\
\hline 971 & $<0.17$ & 1.5 & 0.5 & $10 \mathrm{~N}$ & $<0.17$ & 13.5 & 0.5 \\
\hline 321 & $<0.5$ & 1.5 & $<0.17$ & 21 & 0.17 & 13.5 & 0.17 \\
\hline 577 & $<0.17$ & 1.5 & D & 535 & 0.17 & 0.5 & 0.17 \\
\hline 730 & $<0.17$ & 4.5 & D & 31 & $<0.17$ & 1.5 & $<0.17$ \\
\hline 517 & $<0.17$ & 4.5 & NS & 859 & $<0.17$ & 1.5 & $<0.17$ \\
\hline 505 & $<0.17$ & 4.5 & D & 11 & $<0.17$ & 13.5 & 1.5 \\
\hline 375 & $<0.17$ & 1.5 & NS & 761 & $<0.17$ & 4.5 & 0.17 \\
\hline 719 & $<0.17$ & 13.5 & NS & 711 & 0.17 & 4.5 & 0.5 \\
\hline 727 & $<0.17$ & 1.5 & D & 573 & $<0.17$ & 1.5 & 0.17 \\
\hline 961 & $<0.17$ & 1.5 & E & 981 & $<0.5$ & 1.5 & $<0.5$ \\
\hline 25 & $<0.17$ & 13.5 & E & $5 \mathrm{~N}$ & $<0.17$ & 13.5 & 0.5 \\
\hline 621 & $<0.17$ & 4.5 & NS & 839 & $<0.5$ & 13.5 & 0.5 \\
\hline \multirow[t]{3}{*}{5} & $<0.5$ & 4.5 & E & 245 & $<0.5$ & 40.5 & 0.5 \\
\hline & & & & 883 & $<0.5$ & 0.5 & $<0.17$ \\
\hline & & & & 39 & $<0.5$ & 4.5 & 0.17 \\
\hline
\end{tabular}

NS: no sample. D: dead. E: exported.

recommended that antibody titres equivalent to at least $0.5 \mathrm{IU} / \mathrm{ml}$ be obtained (Anon. 1984). This same titre was also considered to be a good figure for reindeer immunization. Our reindeer were healthy and mature, at least 1.5 years old. The responses of the reindeer in our study at 38 days postvaccination can be regarded as satisfactory, and are of a similiar order to those recorded for cattle (Sihvonen (unpublished data) and Soulebot et al. 1985). One year postvaccination, rabies antibody titres had declined to low levels or disappeared altogether.

All but 1 reindeer responded to the rabies vaccine. The nonresponder had rabies antibody titre $0.5 \mathrm{IU} / \mathrm{ml}$ in all 3 serum samples. The RFFIT-test measures the ability of a specific antibody to inhibit challenge viral growth in a cell culture. The presence in a serum sample of any non-specific (i.e., non-antibody) factors that interfere with cell or viral growth may result in false positive reactions. The 3 $0.5 \mathrm{IU}$ titres of the nonresponding reindeer were considered false positives. Similiar reactions have been recorded in other studies (Campbell \& Barton 1988). Natural infection is improbable because rabies has never been detected in northern Finland. 
Our data show that 1 dose of inactivated rabies vaccine of tissue culture origin induces good but short-term serological conversion in close to $100 \%$ of the reindeer vaccinated. In most reindeer, however, antibody titres do not last for more than a year after primary vaccination. Our results indicate that a booster dose of vaccine is necessary 1 year after primary vaccination to guarantee sufficient protection. Immunological memory of previous experience with rabies vaccine appears to be good. A first annual booster should guarantee solid immunity, and antibodies should be maintained for longer than after primary vaccination (Blancou 1985; Sihvonen et al. (unpublished data)).

\section{References}

Anonymous: WHO Expert Committee on Rabies. Seventh Report, WHO Technical Report Series 709, WHO, Geneva, 1984.

Blancou J: Vaccines and vaccination against rabies for domestic and wild animals in Europe. Rev. sci. tech. Off. int. Epiz. 1985, 4, 249-259.

Campbell JB, Barton LD: Serodiagnosis of Rabies: Antibody Tests. In: Campbell JB, Charlton KM (eds): Rabies. Kluwer Academic Publisher, Boston/Dordrecht/London, 1988, pp. 223-241.

Nyberg M, Kulonen K, Neuvonen E, Ek-Kommonen $C$, Nuorgam $M$, Westerling B: An epidemic of sylvatic rabies in Finland - Descriptive epidemiology and results of oral vaccination. Acta vet. scand. 1992, 33, 43-57.

Soulebot JP, Precausta P, Brun A, Blancou JM, Pepin $M$, Chappuis G, Petermann HG: Immunisation of herbivores against rabies using an inactivated cell culture vaccine. In: Kuwert E, Mereux C, Koprowski H, Bögel K (eds): Rabies in the tropics. Springer-Verlag Berlin 1985, pp. 274-284.

Smith JS, Yaeger PA, Baer GM: A rapid reproducible test for determining rabies neutralizing antibody. Bull. W.H.O. 1973, 48, 535-541.

Turner GS: Humoral and cellular immune responses of mice to rabies and smallpox vaccines. Nature New Biol. 1973, 241, 90-92.

Turner GS: Immunoglobulin (IgG) and (IgM) antibody response to rabies vaccine. J. gen. Virol. 1978, 40, 595-604.

\section{Sammanfattning}

Antikropps-titer hos renar som vaccinerats mot rabies.

En dos inaktiverat, adjuverat rabiesvaccin med cellkulturursprung (Rabisin) gav god men kortvarig immunitet hos så got som samtliga av 50 vaccinerade tamrenar (Rangifer tarandus tarandus L.). 38 dygn efter vaccinationen hade huvuddelen av djuren (44) $\geq 1.5 \mathrm{IU} / \mathrm{ml}$ antikroppar mot rabies i serum. Fem av djuren hade ett titer på $0.5 \mathrm{IU} / \mathrm{ml}$. Ett år efter vaccinationen saknade dock de flesta av djuren antikroppar mot rabies. Av de 39 renar som kunde testas 360 413 dygn efter primärvaccinationen, hade 22 antikropps-titer på $<0.5 \mathrm{IU} / \mathrm{ml}$ i serum.

(Received October 13, 1992; accepted January 15, 1993).

Reprints may be requested from: L. Sihvonen, Department of Production and Vaccines, National Veterinary Institute, P.O. Box 368, SF-00101, Helsinki, Finland. 